\title{
First isolation and characterization of genomic SSR markers for the giant red shrimp Aristaeomorpha foliacea (Risso, 1827)
}

\author{
R. Cannas*, S. Marcias*, F. Sacco, A. Cau and A.M. Deiana \\ Department of Life Sciences and Environment, University of Cagliari, \\ Cagliari, Italy \\ *These authors contributed equally to this study. \\ Corresponding author: R. Cannas \\ E-mail: rcannas@unica.it
}

Genet. Mol. Res. 11 (3): 2745-2748 (2012)

Received September 12, 2011

Accepted May 8, 2012

Published August 17, 2012

DOI http://dx.doi.org/10.4238/2012.August.17.1

\begin{abstract}
Fourteen microsatellite markers were isolated from the giant red shrimp Aristaeomorpha foliacea (Risso, 1827) using the FIASCO protocol (fast isolation by AFLP of sequences containing repeats). Polymorphism was assessed in 30 individuals from two localities of the western Mediterranean basin $(\mathrm{N}=20$ from Sardinia and $\mathrm{N}=10$ from Sicily); nine loci showed polymorphism with 2 to 19 alleles per locus (average: 8.9). Polymorphic information content ranged from 0.36 to 0.91 , and the observed and expected heterozygosities ranged from 0.50 to 0.97 and from 0.47 to 0.93 , respectively. Two loci showed significant deviation from Hardy-Weinberg equilibrium, and evidence of linkage disequilibrium was found for only one locus pair. These loci are the first to be characterized in A. foliacea and could be effective tools for the investigation of genetic diversity, population structure, and demographic connectivity, useful information for the management of this important commercial resource.
\end{abstract}

Key words: Giant red shrimp; Aristaeomorphafoliacea; Microsatellites; FIASCO 


\section{INTRODUCTION}

The giant red shrimp, Aristaeomorpha foliacea (Risso, 1827), is a widely distributed crustacean decapod; it occurs in the Mediterranean Sea, the eastern and western Atlantic, the western Pacific from Japan to Australia, New Zealand, the Fiji Islands and the Indian Ocean (Holthuis, 1980). In the western Mediterranean Sea, A. foliacea has a long traditional and economic significance, where it is the main target species for deep trawl fishery down to a depth of 800-1000 m (Cau et al., 2002), on the contrary in the eastern basin its commercial exploitation has not yet been developed (Cau et al., 2002; Politou et al., 2004).

Recently, the giant red shrimp A. foliacea has been reported to be locally extinct off of the Catalonian coasts (as well as in other areas of the northwestern Mediterranean) at depths of 400$900 \mathrm{~m}$. The modification (increase in salinity) of the Levantine Intermediate Water inhabited by A. foliacea in the western Basin, linked to the Nile damming, was probably a triggering factor for the extinction and/or drop in abundance of this species in the reported areas (Cartes et al., 2011).

Considering the high economic importance and the emerging problems, the assessment of the population structure and connectivity of $A$. foliacea populations using molecular markers could provide important information for the planning of future management efforts.

In this study, for the first time, microsatellite loci were isolated from a partial genomic library of $A$. foliacea following the FIASCO protocol (fast isolation by AFLP of sequences containing repeats) described by Zane et al. (2002).

\section{MATERIAL AND METHODS}

Total genomic DNA was extracted from muscle tissues using the salting out method (Miller et al., 1988). The DNA of five individuals from different locations was pooled and digested with the endonucleases MseI (New England Biolabs) and TaqI (Fermentas). The corresponding adaptors (MseI or TaqI adaptors) were ligated to restricted DNA fragments using T4 DNA ligase (Fermentas), and the ligated products were PCR amplified using primers designed on the adaptors (Vos et al., 1995). PCR was performed on a Mastercycler ep Gradient S (Eppendorf) as described by Zane et al. (2002). The amplified DNA was then enriched using a biotinylated oligonucleotide probe $\left[(\mathrm{AC})_{17}\right]$ and selectively separated using streptavidin-coated beads (Roche Diagnostics) in the presence of a magnetic field (MagnaRack $^{\mathrm{TM}}$, Invitrogen). PCR products were transformed and cloned in the TOPO TA Cloning ${ }^{\circledR}$ kit (Invitrogen); 96 positive clones were PCR amplified with universal vector M13 primers, purified with ChargeSwitch ${ }^{\circledR}$ PCR Clean-Up kit (Invitrogen) and sequenced.

PCR primer pairs were designed using the OLIGO EXPLORER v. 1.2 program $\left(G_{e n e L i n k}{ }^{\mathrm{TM}}\right)$. Forward primers labeled by different fluorescent dyes allowed the detection of fragments on an ABI PRISM 3730xl automated sequencer (ROX 400 as size standard). Allele scoring was done using GeneMarker v. 1.70 (SoftGenetics). The PCR mixtures (25 $\mu \mathrm{L}$ total volume) included $20 \mathrm{ng}$ genomic DNA, $2 \mathrm{mM} \mathrm{MgCl}_{2}, 0.1 \mu \mathrm{M}$ of each primer, 0.2 $\mathrm{mM}$ dNTPs, $2.5 \mu \mathrm{L}$ 10X DreamTaq ${ }^{\mathrm{TM}}$ buffer and $0.8 \mathrm{U}^{\text {DreamTaq }}{ }^{\mathrm{TM}}$ DNA polymerase (Fermentas). A "touchdown" PCR profile (Don et al., 1991) was used for all loci according to the following scheme: initial denaturation step of $94^{\circ} \mathrm{C}$ for 5 min followed by 40 cycles of $94^{\circ} \mathrm{C}$ for $30 \mathrm{~s}$, annealing temperature for $35 \mathrm{~s}$ at different temperatures for each primer pair (Table 1) and decreasing $1^{\circ} \mathrm{C}$ for the subsequent eight cycles, an extension step of $72^{\circ} \mathrm{C}$ for $30 \mathrm{~s}$, and a final extension of $72^{\circ} \mathrm{C}$ for $5 \mathrm{~min}$. 
Polymorphism was screened on 30 individuals from 2 populations: $\mathrm{N}=20$ from Sant'Antioco - southwestern Sardinia, N = 10 from Messina - Sicily. The genotypes were assessed for scoring errors and the presence of null alleles using Micro-Checker v. 2.2.3 (Van Oosterhout et al., 2004). The number of alleles $\left(N_{\mathrm{A}}\right)$, observed $\left(H_{\mathrm{O}}\right)$ and unbiased expected heterozygosities $\left(U H_{\mathrm{E}}\right)$ were calculated with GenAlEx 6.4 (Peakall and Smouse, 2006); the Hardy-Weinberg equilibrium and linkage disequilibrium between loci were tested with GENEPOP v. 4.0 (Rousset, 2008) and Arlequin 3.5 (Excoffier and Lischer, 2010). The polymorphic information content (PIC) index was calculated with Excel Microsatellite Toolkit v. 3.1.1 (Park, 2001).

\section{RESULTS AND DISCUSSION}

Forty-three clones showed a microsatellite repeat, 14 of which with flanking regions of appropriate length and sufficient quality for primer design. The 14 loci were evaluated for primer performance and variation among individuals; 4 of them were rejected due to unsuccessful PCR amplifications and scoring.

The 10 primer pairs available for PCR amplification (Table 1) identified 9 polymorphic microsatellite markers and 1 monomorphic locus. The 9 polymorphic loci showed variability in $N_{\mathrm{A}}$ (from 2 to 19 ) with a mean number of 8.9. PIC ranged from 0.36 to 0.91 ; the $H_{\mathrm{O}}$ and $U H_{\mathrm{E}}$ heterozygosities ranged from 0.50 to 0.97 and from 0.47 to 0.93 , respectively (Table 1). Two loci, Cea17 and Ciea302, showed significant deviations from Hardy-Weinberg expectations for a deficit and excess of heterozygotes, respectively; the possibility is not excluded that these results may be due to the small sample size or the presence of null alleles, confirmed by the results of Micro-Checker for locus Cea17 (Table 1). After sequential Bonferroni's correction for multiple comparisons, loci Cia82 and Ciea317 resulted in linkage (Table 1).

Table 1. Microsatellite loci isolated for Aristaeomorpha foliacea.

\begin{tabular}{|c|c|c|c|c|c|c|c|c|c|}
\hline Locus name & GenBank No. & Repeat motif & Primer sequence $\left(5^{\prime} \rightarrow 3^{\prime}\right)$ & $\begin{array}{l}\text { PCR-TD, } \\
\mathrm{Ta}\left({ }^{\circ} \mathrm{C}\right)\end{array}$ & $\begin{array}{l}\text { Size range } \\
\quad(b p)\end{array}$ & $N_{\mathrm{A}}$ & PIC & $H_{\mathrm{o}}$ & $U H_{\mathrm{E}}$ \\
\hline Cea17 & JN087855 & $(\mathrm{GT})_{11}$ & $\begin{array}{l}\mathrm{F}_{\text {HEx }}: \text { TGAACTATCTGCCACGAGTA } \\
\text { R: GGTGATAGATGAAGACTTGAC }\end{array}$ & $56 \rightarrow 48$ & $156-210$ & 19 & 0.91 & $0.77 * \S$ & 0.93 \\
\hline Cia19 & JN087863 & $(\mathrm{TG})_{13}$ & $\begin{array}{l}\mathrm{F}_{\mathrm{FAM}}: \text { ACACAATATAATGGGAAGACA } \\
\text { R: CACTGTGATGAGCGAATGT }\end{array}$ & $56 \rightarrow 48$ & $158-202$ & 17 & 0.90 & 0.97 & 0.92 \\
\hline Cia57 & JN087856 & $(\mathrm{AC})_{8}$ & $\begin{array}{l}\mathrm{F}_{\text {TAMRA }}: \text { CATGATGTCGGAGGGATGTG } \\
\text { R: GGAATCACAGTGGAAATGGG }\end{array}$ & $61 \rightarrow 53$ & $178-202$ & 9 & 0.55 & 0.70 & 0.58 \\
\hline Cia67 & JN087857 & $(\mathrm{CA})_{6} . .(\mathrm{CA})_{4} . .(\mathrm{CA})_{5} . .(\mathrm{CA})_{4}$ & $\begin{array}{l}\mathrm{F}_{\text {TAMRA }}: \text { GAGTGACGCTGTAGGTGTA } \\
\text { R: ACACAGATAAACAGATGCAGATAT }\end{array}$ & $59 \rightarrow 51$ & $152-170$ & 6 & 0.53 & 0.50 & 0.57 \\
\hline Cia82 & JN087858 & $(\mathrm{CA})_{7} . .(\mathrm{CA})_{12}$ & $\begin{array}{l}\mathrm{F}_{\text {HEx }}: \text { CCTTGCCTAACCTTGACACA } \\
\text { R: GTAACCCTGGGAAACAATGTAA }\end{array}$ & $62.5 \rightarrow 54.5$ & $260-320$ & 7 & 0.48 & 0.57 & 0.54 \\
\hline Ciea253 & JN087859 & $(\mathrm{AC})_{3} . .(\mathrm{AC})_{3} . .(\mathrm{AC})_{5}$ & $\begin{array}{l}\mathrm{F}_{\text {TAMRA }}: \text { GCCGACGGTGAGTTTAATTCG } \\
\text { R: TACATCCACCCGATACCTGA }\end{array}$ & $60 \rightarrow 52$ & $178-204$ & 4 & 0.43 & 0.50 & 0.48 \\
\hline Ciea257 & JN087860 & $(\mathrm{TG})_{14}$ & $\begin{array}{l}\mathrm{F}_{\text {HEx: }}: \text { TCAATGTGATTCTTCTCAGG } \\
\text { R: AAGCATTATCTATACACTTACG }\end{array}$ & $55 \rightarrow 47$ & $183-207$ & 9 & 0.79 & 0.87 & 0.83 \\
\hline Ciea260 & JN087864 & $(\mathrm{AAC}) . .(\mathrm{AAC})_{4} . .(\mathrm{AAC})$ & $\begin{array}{l}\mathrm{F}_{\text {HEx: }}: \text { TGCAGCATGAGAACAGTTG } \\
\text { R: GGGCAAGGCTATTATAACG }\end{array}$ & $58 \rightarrow 50$ & 153 & 1 & 0 & 0 & 0 \\
\hline Ciea302 & JN087861 & $(\mathrm{TG})_{7}$ & $\begin{array}{l}\mathrm{F}_{\text {TAMRA }}: \text { ACCGACAATCTGTGGAACATG } \\
\text { R: GGTTACCAACTCACCTGG }\end{array}$ & $60 \rightarrow 52$ & $204-266$ & 2 & 0.36 & $0.73 * *$ & 0.47 \\
\hline Ciea317 & JN087862 & $(\mathrm{CA})_{3} \mathrm{~A}(\mathrm{CA})_{4}$ & $\begin{array}{l}\mathrm{F}_{\text {FAM: }}: \text { GGAATGGAAATAACTTGCAG } \\
\text { R: TAGAGTTGGGAGTATGAAG }\end{array}$ & $57 \rightarrow 49$ & $260-320$ & 7 & 0.48 & 0.75 & 0.54 \\
\hline
\end{tabular}

Dye label is given for each forward primer. PCR-TD = amplification by touchdown (see text for details); Ta = annealing temperature for the first and final cycles; $N_{\mathrm{A}}=$ number of alleles; PIC = polymorphic information content; $H_{\mathrm{O}}=$ observed heterozygosity; $U H_{\mathrm{F}}=$ unbiased expected heterozygosity. Locus that deviates significantly from Hardy-Weinberg equilibrium for a *deficit or **excess of heterozygotes after sequential Bonferroni's correction for multiple tests; ${ }^{\S}$ probable presence of null alleles according to Micro-Checker; loci indicated in bold are in linkage equilibrium. 
These loci are the first to be characterized in A. foliacea and could be effective tools for the investigation of genetic diversity, population structure, and demographic connectivity, useful information for the management of this important resource.

\section{ACKNOWLEDGMENTS}

The authors thank Dr. Paola Rinelli (CNR Messina) for providing the Sicilian samples.

\section{REFERENCES}

Cartes JE, Maynou F and Fanelli E (2011). Nile damming as plausible cause of extinction and drop in abundance of deepsea shrimp in the western Mediterranean over broad spatial scales. Prog. Oceanogr. 91: 286-294.

Cau A, Carbonell A, Follesa MC and Mannini A (2002). MEDITS-based information on the deep-water red shrimps Aristaeomorpha foliacea and Aristeus antennatus (Crustacea: Decapoda: Aristeidae). Sci. Mar. 66: 103-124.

Don RH, Cox PT, Wainwright BJ, Baker K, et al. (1991). 'Touchdown' PCR to circumvent spurious priming during gene amplification. Nucleic Acids Res. 19: 4008.

Excoffier L and Lischer HEL (2010). Arlequin suite ver 3.5: a new series of programs to perform population genetics analyses under Linux and Windows. Mol. Ecol. Res. 10: 564-567.

Holthuis LB (1980). Shrimps and Prawns of the World. An Annotated Catalogue of Species of Interest to Fisheries. FAO, Rome.

Miller SA, Dykes DD and Polesky HF (1988). A simple salting out procedure for extracting DNA from human nucleated cells. Nucleic Acids Res. 16: 1215.

Park SDE (2001). Trypanotolerance in West African Cattle and the Population Genetic Effects of Selection. Ph.D. thesis, University of Dublin, Dublin.

Peakall R and Smouse PE (2006). GENALEX 6: genetic analysis in Excel. Population genetic software for teaching and research. Mol. Ecol. Notes 6: 288-295.

Politou CY, Kapiris K, Maiorano P and Capezzuto F (2004). Deep-sea Mediterranean biology: the case of Aristaeomorpha foliacea (Risso, 1827) (Crustacea: Decapoda: Aristeidae). Sci. Mar. 68 (Suppl. 3): 129-139.

Rousset F (2008). GENEPOP'007: a complete reimplementation of the Genepop software for Windows and Linux. Mol. Ecol. Res. 8: 103-106.

Van Oosterhout C, Hutchinson WF, Wills DPM and Shipley P (2004). Micro-Checker: software for identifying and correcting genotyping errors in microsatellite data. Mol. Ecol. Notes 4: 535-538.

Vos P, Hogers R, Bleeker M, Reijans M, et al. (1995). AFLP: a new technique for DNA fingerprinting. Nucleic Acids Res. 23: 4407-4414

Zane L, Bargelloni L and Patarnello T (2002). Strategies for microsatellite isolation: a review. Mol. Ecol. 11: 1-16. 